\title{
Implementing Standardization Education at the National Level
}

\author{
Henk J. de Vries
}

\begin{tabular}{|l|l|}
\hline \multicolumn{2}{|l|}{ ERIM REPORT SERIES RESEARCH IN MANAGEMENT } \\
\hline ERIM Report Series reference number & ERS-2011-007-LIS \\
\hline Publication & March 2011 \\
\hline Number of pages & 14 \\
\hline Persistent paper URL & http://hdl.handle.net/1765/22812 \\
\hline Email address corresponding author & hvries@rsm.nl \\
\hline Address & Erasmus Research Institute of Management (ERIM) \\
& RSM Erasmus University / Erasmus School of Economics \\
& Erasmus Universiteit Rotterdam \\
& P.O.Box 1738 \\
& 3000 DR Rotterdam, The Netherlands \\
& Phone: + 31 10 408 1182 \\
& Fax: + 3110 408 9640 \\
& Email: info@erim.eur.nl \\
& Internet: $\quad$ www.erim.eur.nl \\
\hline
\end{tabular}

Bibliographic data and classifications of all the ERIM reports are also available on the ERIM website: www.erim.eur.nl 


\section{ERASMUS RESEARCH INSTITUTE OF MANAGEMENT}

\section{REPORT SERIES}

\section{RESEARCH IN MANAGEMENT}

\begin{tabular}{|l|l|}
\hline \multicolumn{2}{|l|}{ ABSTRACT AND KEYWORDS } \\
\hline Abstract & $\begin{array}{l}\text { This paper explores how standardization education can be implemented at the national level. } \\
\text { Previous studies form the main source for the paper. This research shows that implementation of } \\
\text { standardization in the national education system requires policy at the national level, a long term } \\
\text { investment in support, and cooperation between industry, standardization bodies, academia, } \\
\text { other institutions involved in education, and government. The approach should combine bottom- } \\
\text { up and top-down. The paper is new in combining previous findings to an underpinned } \\
\text { recommendation on how to implement standardization education. }\end{array}$ \\
\hline Free Keywords & standardization education, national strategy, policy development \\
\hline Availability & $\begin{array}{l}\text { The ERIM Report Series is distributed through the following platforms: } \\
\text { Academic Repository at Erasmus University (DEAR), DEAR ERIM Series Portal } \\
\text { Social Science Research Network (SSRN), SSRN ERIM Series Webpage } \\
\text { Research Papers in Economics (REPEC), REPEC ERIM Series Webpage }\end{array}$ \\
\hline Classifications & $\begin{array}{l}\text { The electronic versions of the papers in the ERIM report Series contain bibliographic metadata } \\
\text { by the following classification systems: } \\
\text { Library of Congress Classification, (LCC) LCC Webpage } \\
\text { Journal of Economic Literature, (JEL), JEL Webpage } \\
\text { ACM Computing Classification System CCS Webpage } \\
\text { Inspec Classification scheme (ICS), ICS Webpage }\end{array}$ \\
\hline
\end{tabular}




\title{
Implementing standardization education at the national level ${ }^{1}$
}

\author{
Henk J. de Vries, Rotterdam School of Management, Erasmus University, the Netherlands
}

\begin{abstract}
This paper explores how standardization education can be implemented at the national level. Previous studies form the main source for the paper. This research shows that implementation of standardization in the national education system requires policy at the national level, a long term investment in support, and cooperation between industry, standardization bodies, academia, other institutions involved in education, and government. The approach should combine bottom-up and top-down. The paper is new in combining previous findings to an underpinned recommendation on how to implement standardization education.
\end{abstract}

Keywords: Standardization education, National strategy, Policy development

Interest in standardization education is growing. In Indonesia, for instance, the number of universities cooperating with the Indonesian national standards body BSN to address standardization has increased from none in 2007 to 23 in 2010 (Odjar Ratna Komala, 2011). South Korea is at the forefront of implementing standardization education in academic curricula and does more than Europe as a whole (Choi (Ed.) 2008, Czaya et al. 2010). Starting from scratch in 2003 (KSA, 2003) Korea has managed to get standardization education implemented at several levels, in particular universities and elementary schools, amounting to 7,490, 10,486 and 9,503 students in 2008, 2009 and 2010, respectively. Standardization education is emerging in other Asian countries as well, both at the academic level and at lower levels including secondary and even elementary schools. Standardization education increases awareness of standards and standardization and prepares people for jobs in which they have standards-related tasks. In this paper, we investigate what could be done at the national level to stimulate standardization education.

The need for education about standardization has been addressed in several studies (Verman, 1973; Korukawa 2005; de Vries, 2005; de Vries and Egyedi, 2007; Krechmer, 2007; Cooklev, 2010). Implementing standardization education is not easy and despite its recent growth, it is an exception rather than a rule that the topic of standardization is included in education. A combination of barriers has to be overcome. A first barrier relates to the image of standardization. Students may perceive standardization to be 'dull' and if it is the main topic of an elective course, they may choose another, seemingly more appealing course. A second barrier is related to teachers: they may be reluctant to address standardization, because 1) they may be

\footnotetext{
${ }^{1}$ Paper to be published in the International Journal of IT Standards and Standardization Research, Vol. 9, No. 2, July - December 2011.
} 
afraid that the topic fails to attract students (this is related to the first barrier), 2) they are not familiar with the topic, 3) they are not aware of its importance, and/or 4) the curriculum is already overloaded. The situation would be different if teachers were required to focus on standardization, but who should convince those who determine curricula and define the final attainment level for students? Standards bodies, of course, are aware of the importance of standards and standardization because it is their core business but should they take initiatives to promote standardization education? What about industry and governments? What role should they play and how aware are they of the importance of standardization as such and standardization education in particular? Lack of awareness on their side may be a third barrier (de Vries et al., 2009).

The 2006 standardization education workshop organized by the International Cooperation for Education about Standardization (ICES) concluded that if standards bodies or other stakeholders take the initiative to promote standardization education, success of implementation depends on (1) national policy, (2) the availability of resources at the national level, and (3) close cooperation between industry, standards bodies, academia, other organizations in the field of education, and government (de Vries and Egyedi, 2007). These elements will be addressed in the subsequent sections. The concluding section describes what steps could be taken to promote and implement standardization education.

\section{NATIONAL POLICY}

Developing and deploying a national standardization education strategy and policy is a prerequisite for a systematic national approach to standardization education (Choi et al., 2009; DeNardis and Levin, 2009).. The creation of a national standardization education strategy in APEC member countries was stimulated by a decision taken at the $18^{\text {th }}$ APEC Ministerial Meeting in Hanoi, Vietnam, in November 2006: 'The ministers of the Asia Pacific Economic Cooperation recognized the importance of standards education and encouraged their members to develop reference curricula and materials to address the significance of standards and conformance to trade facilitation in the region' (APEC, 2006). Following this decision, a project was set up and led by the Korean Standards Association (KSA) (Choi (Ed.), 2008). It includes the development of curricula and teaching materials, and the training of teachers. Most APEC member countries now have a national standardization education strategy. This strategy can be broad (addressing many areas of education) or limited and it can be detailed (specifying exactly what will be done when by whom) or global. It seems that the broader and more detailed the strategy, the more standardization education activities are in place in a country (Choi et al., 2009; Choi and de Vries, 2011). At the European level, the European Commission 'encourages the Member states to improve the position of standardisation in education programmes and academic curricula, in order to familiarise students with the strategic benefits and challenges of standardisation, drawing on the expertise of standardisation bodies' (Council of the European Union, 2008, Conclusion 27). Referring to this resolution, the CEN/CENELEC/ETSI Joint Working group on Education about Standardization (Ketchell, 2010) is preparing a standardization education policy document which can serve as an example for national standardization education policies. 


\section{INVESTING IN ONGOING SUPPORT}

However, a national strategy is not sufficient. Korean and Dutch examples show that a long-term investment in time (and thus money) is needed in the form of one or more dedicated people who actively approach and support schools in developing, implementing and maintaining education.

In the Korean case, the Korean Standards Association took the lead and managed to get education about standardization implemented in bachelor programs of engineering education all over the country. They established a Standards Education Development Committee composed of participating professors and lecturers. This committee networked with standards experts from various fields in the Republic of Korea and developed a curriculum and educational materials. The Korean government provided financial support (Lee, 2007). The personal efforts of a KSA staff member, Danbee Kim, seem to have been decisive for the success of the project.

The Dutch case did not focus on standardization education but on a similar topic: intellectual property rights (IPR) in higher professional education. This subject has now been integrated in several compulsory courses in higher professional education and elective courses have been developed. It all began when the patent office approached an institution for higher professional education a few kilometres from their office. They established contacts with teachers, one of whom was offered for an internship at the patent office. He became the patent and IPR expert within his school and developed an elective course on patents together with patent office staff. The course is open to students from all technical disciplines. Other teachers were stimulated and started to introduce the topic into their courses. Starting with this one school, this approach was used at other schools of higher professional education in the country and $100 \%$ coverage has been achieved. The patent office stays in touch with the schools to increase awareness of the topic and its importance. It does so by arranging guest lectures, and providing teaching materials co-developed with teachers, exam questions, access to the patent database, and advice about how to include the topic in the final attainment level students should reach when leaving the school. The patent office is also in close contact with school boards, the national association of schools, and the national association of engineers. Moreover, there is a link to the education officer of the FME Association, the largest organization in the Netherlands representing employers and businesses in the technology sector. To enable these activities, the patent office has a dedicated officer for higher professional education available. From this level of education, the patent office has expanded its activities to a higher level (universities) and a lower level of technical education (intermediate technical schools) for which staff capacity is also available. As a governmental agency, the patent office is funded for these tasks by the national government (de Vries, 2003, pp. 14-15) $)^{2}$.

The Korean and Dutch examples and the literature show the following typical elements of a successful national approach:

- An inventory of needs for education (de Vries \& Egyedi, 2007)

- A steering group in which the most important stakeholders are represented (industry, standards bodies, government, organizations in the field of education)

- An action plan

- One or more dedicated staff members who are available for a period of years

- Funding for salaries and other costs

\footnotetext{
${ }^{2}$ See for the services offered http://www.octrooicentrum.nl/index.php/Producten-endiensten/onderwijsmateriaal12.html (in Dutch language).
} 
- Development of curricula and materials

- A train-the-teachers programme

- Promotional activities

Activities can start with one or a few teachers from one or a few schools and from there expand to a growing number of schools. Additionally, an approach for teaching practitioners is needed (Choi \& De Vries, 2011; Giossi, 2010).

\section{BRIDGING FIVE WORLDS: INDUSTRY, STANDARDIZATION BODIES, ACADEMIA, OTHER INSTITUTIONS FOR EDUCATION, AND GOVERNMENT}

A third requirement for successful implementation of standardization education is to bridge five worlds that are all involved in some way with standardization but are not always aware of each others' interests and capacities: industry, standards development organizations, academia, other institutions for education, and government. At the end of the day, industry and other stakeholders need employees' awareness of standards and standardization, and industry, government, standards development organization and other organizations need qualified people to do standards-related tasks. Academic and other education is needed to provide this qualification.

Standardization can be seen as a discipline for which education is needed (Verman, 1973; de Vries, 2002). But is it a discipline? 'Standards and standardization have yet to reach the status of an academic discipline in their own right, while on the other hand they cannot be classified under one of the accepted academic disciplines, such as engineering or social sciences' (Hesser, 1997, p. 3). De Vries (1999, Section 1.1.3) elaborates the idea of standardization as a discipline using the periods in the development of a scientific discipline developed by Kuhn (1962). The current trend to pay more attention to standardization education (Kurokawa, 2005; de Vries and Egyedi; 2007) should be seen as a normal step in the development of standardization into a more mature discipline (de Vries, 2002). A discipline needs professionals with professional education, and professional and scientific journals publishing results of illustrative best practice cases and scientific research.

\section{Industry}

The need for standardization education in industry is latent rather than manifest. Take the example of industry participants in international standardization. Research has revealed more than a hundred factors that contribute to successful participation in international standardization committees (Brons, 2007). Most participants in international standardization are not aware of these factors. They spend several days or weeks a year in standardization activities and have the illusion they are doing a good job but are not aware that their efforts could be much more effective.

A professional community is needed to enhance professionalization of standards experts in industry. The national members of the International Federation of Standards Users IFAN, such as the Standards Engineering Society SES in the United States and Canada, form such communities where standards experts can share knowledge and experience. However, we can observe a paradoxical situation. Membership in both IFAN and most national standards users 
organizations, except in some Asian countries, has decreased recently although the importance of standards and standardization has increased (de Vries, 1999; Kurokawa, 2005; Swann, 2010). How can this paradox be explained? Traditionally, the members of these national organizations are managers of standardization departments in large companies or standards experts in mediumsized companies (Adolphi, 1997) and thus they are not only standards users (who use standards for their products, services, processes, etc.) but also standards developers (developers of company standards for use within their company or participants in standardization committees at the national or international level, in formal standards bodies or in industry consortia). However, many companies have eliminated standardization departments or reduced the number of staff. Reasons for this reduction include:

- Lack of awareness of the strategic importance of standardization.

- Standardization has an image problem. 'In Japan, there is a tendency for standardization personnel not to be assigned important roles in organizations, even in industries where standards are emphasized' (Kurokawa, 2005, p. 41). It is the author's experience that the same applies in other countries.

- Staff cost as a percentage of total cost has increased because the cost of machines and other equipment has decreased.

- Standardization requires a medium to long-term business perspective because standards, by definition, "freeze" a specification for a certain period of time until a new standard is developed, which may take several years. Cost precedes benefits. The growing emphasis on short-time financial returns makes it easy to justify cuts of standards-related activities.

- More standards-related tasks are being outsourced, e.g. updating the standards collection to a standardization body or a company.

These reasons, in particular the first one, provide a further underpinning of the need to address standards in technical but also in business education. However, the current under-evaluation of standards and standardization hinders the initiation of standardization education activities. What is needed is a clear and strong signal from industry that such education is needed. However, as long as industry and its associations lack awareness of the importance of standardization, this is not likely to happen. So to a certain extent there is a vicious circle. This could be broken by highlighting cases of companies that have managed to gain a competitive advantage by using standards or by being involved in standardization. For example, the German ISO member DIN presents an annual award for the best entries demonstrating the benefits of standardization. ${ }^{3}$

If companies recruit fewer standards experts whereas standards and standardization are becoming more important, there should be a market for intermediary parties such as trade associations or consultancy firms to support companies in standards activities. Perhaps future standards experts will no longer be recruited by companies but by these intermediary parties instead. However, a mixed situation is more plausible, with big companies having their own experts and SMEs relying more on external advice (de Vries et al, 2009) and both companies and intermediaries represented in national associations of standards experts.

More about industry needs for standardization education can be found in Kurokawa (2005) and De Vries and Egyedi (2007). They conclude that general education should provide awareness about standards and standardization. This awareness should enable graduates, once they have a job in industry or in another sector, to recognize if they need further education. Additionally, regular education may prepare students, in particular in technical, business and

\footnotetext{
${ }^{3}$ See http://www.din.de/cmd?level=tplrubrik \&menuid $=47388 \& \mathrm{cmsareaid}=47388 \&$ menurubricid $=47468 \& \mathrm{cmsrubid}=47468 \&$ languageid $=\mathrm{de}$.
} 
economic and law studies, for their future jobs by teaching more than just awareness. And last but not least, thorough academic education is needed to prepare people who can improve the current standardization system and to further develop standardization as a discipline.

A few examples show that industry has taken initiative to stimulate standardization education. At the international level, the initiative to create the International Cooperation for Education about Standardization ICES was taken by industry (John Hill, Sun Microsystems, USA and Toshiaki Kurokawa, CSK Corporation, Japan). The International Federation of Standards Users IFAN has established a working group to stimulate standardization education. At the European level, Orgalime (European Engineering Industries Association) has emphasized the need for standardization education in policy papers (Orgalime, 2010a; Orgalime, 2010b).In the Netherlands, the FME Association, representing companies in the technology industry, has developed activities to support education including a working group of teachers in higher professional education. The Association has also stimulated the inclusion of standardization in curricula via this group (de Vries, 2003). SES, the standards users organization in Canada and the US, offers an introduction course about standardization (http://www.ses-standards.org).

\section{Standardization bodies}

Standards and standardization are the core business of standardization bodies, so one would expect them to be centers of standardization expertise. In South Korea, it was the trade union of employees of KSA that saw the need to professionalize KSA staff and this is the reason that they initiated a workshop which formed the start of academic standardization education activities (KSA, 2003). DIN staff are required to successfully follow standardization courses (Behrens, 2010). However, such recognition of the importance of real standardization expertise for standardization bodies is not widespread.

Part of the professionalization of international standardization could thus be to better educate technical officers of standardization bodies. The system of international standardization could be upgraded by granting ISO and IEC secretariats only to technical officers with a recognized diploma in standardization. This is self-evident in other professional areas from accountants to bus drivers but so far not required for experts who provide standardization services. A first step in this direction is the certification programme established by SES to recognize people who have demonstrated a high degree of professional competency in standardization (http://www.sesstandards.org).

Many standardization organizations provide standardization activities themselves, mostly for business people but sometimes also in regular education (Choi (Ed.), 2008). The academic week organized by the international standardization organizations ISO, IEC and ITU (http://www.iso.org/sites/WSCAW2010/index.html), the ISO award for Standardization in higher Education (ISO, 2011), the IEC lecture series (IEC, 2005; IEC, 2007) and the ITU Kaleidoscope conferences (http://www.itu.int/ITU-T/uni/kaleidoscope) are examples of how international standards bodies reach out to the academic community. National standards bodies have similar initiatives, for instance the Korean standards bodies, Korean Agency for Technology and Standards KATS and the Korean Standards Association KSA, established the Society for Standards and Standardization SSS, an academic association also open to practitioners. SSS took off in October 2010 with an international symposium on "Promotion of Research Activities on Standardization" (ISO Focus,+ 2011$)$. 


\section{Academia}

A limited number of university professors pay attention to standardization in their education and research activities. In most cases, it is only one of the many topics they address. The number of standardization chairs is very limited. In terms of size of standardization staff, China Jiliang University in Hangzhou, winner of the first ISO Award on Higher Education in Standardization 2007, is the number one in the world (Song, 2007 and Yang, 2010). Until recently, the second largest standardization research group was at the Helmut Schmidt University in Hamburg (Hesser and Czaya, 1999). Prof. Blind's Chair at the Technical University in Berlin can be seen as a successor though its scope is broader than just standardization. In Japan, the Tokyo University of Agriculture and Technology addresses standardization in its Management of Technology programme (Furukawa, 2007; Nonaka, 2010). Other universities with standardization programs include the Belarussian National Technical University (Serenkov, 2010), the French Ecole Internationale des Sciences du Traitement de l'Information (BeauvaisSchwartz and Bousquet, 2010) and the French University of Technology of Compiègne (Caliste and Farges, 2007).

The situation in the Netherlands is unique and might serve as a benchmark for other countries. The Dutch ISO member, NEN, created an endowed chair in standardization at the Rotterdam School of Management (RSM), Erasmus University in 1994. "Endowed" means that NEN pays the professor, currently Prof. Dr. Knut Blind, for his appointment on a one-day-aweek basis. NEN provides additional funding so that he can receive support. Besides providing standardization education at its own university, the chair does the following activities:

- Supports standardization research and education at other universities (by organizing, maintaining and supporting an informal network of academic researchers in standardization encompassing nine of the 12 Dutch universities).The Netherlands Standardization Institute NEN, the Dutch Council for Accreditation RvA, the Dutch standards users organization NKN and the Dutch Ministry of Economic Affairs also participate in this network, which allows for informal links with major stakeholders.

- Gives "status" to the topic of standardization by the simple fact the university has an endowed chair.

- Further develops standardization as a scientific discipline.

- Participates in policy debates, for instance, on how to improve national environmental policy by making use of standards. In some cases, the opinion of a professor is more convincing than that of the general director of a standards body.

Additionally, RSM students help NEN with feasibility studies for new standardization topics which has resulted in new activities for NEN. Five students educated at RSM have been recruited by NEN. RSM advice has contributed to better stakeholder involvement in NEN, the number of participants has increased by $30 \%$ which has also contributed to NEN's healthy financial results (NEN, 2010). Apparently, NEN gets a return on its investment in the chair.

Establishing an academic community is essential primarily for research but also for education. The European Academy for Standardisation EURAS (http:/www.euras.org) is an established community of standardization researchers although membership is open to nonacademics as well. EURAS' main activity is its annual conference. A EURAS working group is currently investigating user needs for standardization education. The organization is represented in the CEN/CENELEC/EURAS Working Group on Education about Standardization, and is 
preparing a White Paper on Standardization Education. The SIIT conferences (Standardization and Innovation in Information Technology) form another place for standardization researchers to meet. Four countries have an academic community at the national level: Korea, the Netherlands, Bulgaria and Greece. The Bulgarian Union of Standardization for European Integration of the Republic of Bulgaria was established in 1991 to support the transition of Bulgaria from a planned/socialist economy to a market economy. Besides academic research and education, many seminars are organised for industry, in particular for SMEs (Ganeva et al., 2010). In Greece, Eneprot was established in 1997. This official organization focuses on academic research and education but supports SMEs. Eneprot took the initiative for a series of international conferences on "Standardization, Protypes and Quality: A means of Balkan Countries Collaboration" (Zachariadou et al., 2010).

Academic journals are another prerequisite for the development of a discipline. Standardization journals include the EURAS Yearbook of Standardisation (special issues of Homo Oeconomicus), the International Journal of IT Standards and Standardization Research, the International Journal of Services and Standards, and Computer, Standards \& Interfaces. However, these journals have not yet achieved a scientific reputation in the set of management and economics journals needed to attract a sufficient number of excellent scientific contributions pushing the scientific progress in standardization research. Special issues on standardization of Réseaux (2000), Knowledge, Technology, \& Policy (2001), Telecommunications Policy (2002), MIS Quarterly (2006), Revue d'Économie Industrielle (2006), Organization (2007), Entreprises et Histoire (2008), Technology Analysis and Strategic Management (2011) and Organization Studies (2011) have brought or are expected to bring standardization research to the attention of a broader academic audience. The more standardization is addressed in academic research, the more scientific researchers will be inclined to include it in their teaching activities.

\section{Other education institutions}

Standardization education is not only relevant at the academic level. In the Netherlands, the first case of successfully implementing education about IPRS was in higher professional education and this level was and is the first target group. From there, it was extended to senior secondary vocational education and universities. Also secondary schools are relevant and Thailand and Turkey are successful examples (Choi (Ed.), 2008). Compared with universities, other schools have less freedom to address their preferred subjects. Therefore, including standardization in the final attainment levels will stimulate adoption. However, this can only be achieved by involving individual teachers and schools but also associations and other organizations active in the organization of education at the national level.

\section{Government}

National governments play different roles related to standards and standardization (De Vries, 1999, Section 2.2.5). These include:

1 Supporting standardization as a part of their general role in stimulating business performance and international trade. 
2 Creating a legal foundation for standardization - many countries have legislation setting criteria for the national standardization institute (Schepel, 2005).

3 Carrying out standardization activities themselves (in many countries, in particular in the former Soviet Union and in developing countries, the national standardization organisation is a governmental agency).

4 Supplementing, simplifying, or improving their legal system with standardization by making references to standards in laws.

5 Using standardization for specific public sector tasks (for instance, in the areas of public health, environmental protection, traffic infrastructure, army, and police. Then governmental interests are comparable to those of companies with a dominant market position or companies as main users).

6 Using standardization to improve their performance in areas that are not specifically governmental (for instance, procurement, IT systems, occupational health and safety of government workers).

In all these roles the government would benefit from better standardization education. Government officers in charge of roles 2, 3 and 4 need very specific standardization education. For role 1 , standardization education is one of the policy instruments the government might use. Moreover, government has a seventh role: it is responsible for education. The government could include standardization knowledge in its criteria for accreditation of educational programs (Spivak and Kelly, 2003; Cooklev, 2010).

Many governments are insufficiently aware of these $t$ roles and lack a policy that addresses them. An exception is the policy of the German government which focuses on the first role but also mentions all other roles except 3 (not applicable) and except the governmental responsibility for education (Die Bundesregierung, 2009).

\section{THE PROCESS TOWARDS MORE STANDARDIZATION EDUCATION}

We started this paper with three barriers for the implementation of standardization education. The first barrier might be the most difficult to overcome: how can we make the topic of standardization more appealing to students? Attractive teaching approaches and materials may partly solve this problem - and students may well pass on their enthusiasm to fellow students. De Vries and Egyedi (2007) have examined teaching materials and new materials and approaches including games are being developed. But this does not completely solve this problem. Elective courses focused on standardization only may lack appeal to students. Including it in other courses or as a compulsory part of the curriculum could be a solution.

The second barrier relates to teachers' willingness to include the topic in their courses. The Dutch and Korean examples suggest a combination of 'top-down' and 'bottom up'. The process is top-down in the sense that a decision is taken at central level, funding is available, and staff for coordination and support is available. The process is bottom-up in the sense that individual teachers and their management need to be convinced that standardization is an important subject and should form part of the curriculum. This is not easy because the curricula are already full and the topic has to compete with other more established ones. It would be particularly convincing if industry and government acknowledged the importance and the need for standardization and strongly urged (or recommended) it be included in educational programs. This can be achieved by setting up a standardization education steering group at the national level in which industry, 
government, standards body and academia plus other educational institutions are represented. This group can also facilitate another 'top-down' process: to get standardization included in the official final attainment level for graduating students. This may not apply for universities, but probably does for lower levels of education. This requires considerable lobbying which will be easier if some education is in place already. Where applicable, reference to APEC or EU policies or to national standardization strategies (APEC, 2006; Choi et al., 2009; Council of the European Union, 2008, Conclusion 27) can be made. Participation in a national steering group increases awareness of the importance of standardization education for industry and government representatives - the third barrier. Their awareness and subsequent involvement is needed to gain momentum at the national level and this, in turn, may convince schools and their teachers to include standardization in the curriculum. Moreover, it may mobilize resources needed for the investment in standardization education.

Education is organized mainly at the national level so this is the natural level for starting initiatives. In some big countries, initiative taking could also occur at a regional level. Moreover, in a growing number of cases, national boundaries are no longer relevant - this applies to multinational companies and NGOs, and Internet communities. At the global level, ideas and approaches can be exchanged using the platform of the International Cooperation on Education about Standardization ICES (http://www.standards-education.org). International standardization have an additional role in developing teaching materials and in providing assistance or even education in countries where no standardization education is in place yet (Gerundino, 2010).

In South Korea, the initiative for standardization education was taken by an unexpected stakeholder: a trade union. This shows that any party can take the initiative - the standards body, industry, government, a university or any other stakeholder. The role of the initiator is to involve other stakeholders. The APEC inventory shows that national standards bodies play an important role in each country that has successfully implemented standardization education (Choi (Ed.), 2008). Next, resources are needed to employ dedicated people for some years, to develop educational materials and to organize train-the-trainer programs etc. These resources could come from industry, from standards bodies (with some delay, it will enhance their market position but cost precedes benefits), or from government (in the European case from the European Commission).

\section{FUTURE RESEARCH}

Meanwhile, initiatives for more standardization education are taken all over the world. Future research might make an inventory of initiatives and achievements and relate impact to measures taken. In-depth case studies might provide best practice examples. In particular, the Korean case deserves further investigation. Another opportunity is to benchmark the introduction of standardization education with other topics of education, such as the similar topic of IPR. Above we mentioned the example of IPR education in the Netherlands. Another country for such research is Japan where a steady increase in IPR education can be observed (Yamada, 2011). In such studies, authors might borrow from literature on 'educology' - the field of research that studies educational processes. 


\section{REFERENCES}

Adolphi, H. (1997). Strategische Konzepte zur Organisation der betrieblichen Standardisierung. DIN Normungskunde Band 38. Berlin: Beuth Verlag.

APEC (2006). The eighteenth APEC ministerial meeting joint statement. Singapore: APEC.

Beauvais-Schwartz, N. and Bousquet, F. (2010). France - Fostering competitive intelligence. Retrieved May 26, 2010, from http://www.iso.org/iso/iso-focus-plus index/isofocusplus online-bonus-articles/the-2009-iso-award/2009-award france.htm.

Behrens, H. (2010). Education about Standardization - Competency of Standards Body Staff. Presentation at the first meeting of the CEN/CENELEC/ETSI Joint Working Group on Education about Standardization, 2010-03-09, Brussels. JWG-EaS N008. Brussels: CENCENELEC Management Centre.

Brons, T.F. (2007). Effective Participation in Formal Standardization: A Multinational Perspective. Rotterdam: Rotterdam School of Management.

Caliste, J. \& Farges, G. (2007). A French University: Encouraging hands-on experience. ISO Focus, 4(11), 13-14.

Choi, D. (Ed.) (2008). APEC SCSC Education Guideline 1: Case Studies of How to Plan and Implement Standards Education Programs, Asia Pacific Economic Cooperation. Singapore: APEC Secretariat.

Choi, D. \& de Vries, H.J. (2011). Standardization as emerging content in technology education. International Journal of Technology and Design Education. 21(1), 111-135. Retrieved from http://www.springerlink.com/content/77566372j57240j1

Choi, D., de Vries, H.J. \& Kim, D. (2009). Standards Education Policy Development: Observations based on APEC Research. International Journal of IT Standards and Standardization Research, 7(2), 23-42.

Cooklev, T. (2010). The Role of Standards in Engineering Education. International Journal of IT Standards and Standardization Research, 8(1), 1-9.

Council of the European Union (2008). Council Conclusions on standardisation and innovation. $2891^{\text {st }}$ Competitiveness Council meeting, 2008-09-25. Brussels: Council of the European Union.

Czaya, A., Egyedi, T. \& Hesser, W. (2010). The current state of standardization education in Europe. In Mijatovic, I. and Živković, N. (Eds.), Proceedings $7^{\text {th }}$ International Conference "Standardization Protypes and Quality: A means of Balkan countries collaboration", pp 8590. June 8-9, 2010 Zlatibor, Serbia. Belgrade: University of Belgrade, Faculty of Organizational Sciences.

de Vries, H.J. (1999). Standardization - A Business Approach to the Role of National Standardization Organizations. Boston / Dordrecht / London: Kluwer Academic Publishers.

de Vries, H.J. (2002). Standardization - Mapping a field of research. In Sherrie Bollin (Ed.), The Standards Edge, pp 99-121. Ann Arbor, MI: Bollin Communications.

de Vries, H.J. (2003). Kenbaarheid Normalisatie en Normen - Deelproject $9 b$ HBO-onderwijs Tussenrapportage. Delft: NEN.

de Vries, H.J., Blind, K., Mangelsdorf, A., Verheul, H., van der Zwan, J. (2009). SME Access to European Standardization - Enabling small and medium-sized enterprises to achieve greater benefit from standards and from involvement in standardization. Brussels: CEN and CENELEC. Retrieved from http://www.cenelec.eu/NR/rdonlyres/88D06BD5-CA51-479DA416-AB1F3BE67E66/0/SMEAccessReport20090821.pdf. 
de Vries, H.J.\& Egyedi, T.M. (2007). Education about Standardization - Recent Findings. International Journal for IT Standards and Standardization Research, 5(2), 1-16.

Denardis, L. \& Levin, A. (2009). Bridging the standardization gap - ITU-T Research Project: Measuring and Reducing the Standards Gap. Geneva: International Telecommunication Union.

Die Bundesregierung (2009). Normungspolitisches Konzept der Bundesregierung. Berlin: Die Bundesregierung.

Furukawa, Y. (2007). A Japanese university: Educating standardization strategists in business. ISO Focus, 4(11), 15-16.

Ganeva, L., Sandalski, B. \& Kotev, R. (2010). Contributions of the Bulgarian Union of Standardization for the European Integration of the Republic Bulgaria. In: Mijatovic, I. and Živković, N. (Eds). Proceedings $7^{\text {th }}$ International Conference "Standardization Protypes and Quality: A means of Balkan countries collaboration”, pp 29-38. June 8-9, 2010 Zlatibor, Serbia. Belgrade: University of Belgrade, Faculty of Organizational Sciences.

Gerundino, D. (2010). Standards in economic development and trade. ISO Focus +, 1(1), 35.

Giossi, S. \& Papastamatis, A. (2010). The effective teaching of standards in a lifelong learning world. In Mijatovic, I. and Živković, N. (Eds). Proceedings $7^{\text {th }}$ International Conference "Standardization Protypes and Quality: A means of Balkan countries collaboration", pp 118125. June 8-9, 2010 Zlatibor, Serbia. Belgrade: University of Belgrade, Faculty of Organizational Sciences.

Hesser, W. (1997). The need for interdisciplinary research on standardization. Presentation for the SCANCOR/SCORE Seminar on Standardization, Lund, Sweden. Hamburg: Professur für Normenwesen und Maschinenzeichnen, Universität der Bundeswehr Hamburg.

Hesser, W. and Czaya, A. (1999). Standardization as a subject of study in higher education. ISO Bulletin, 30(6), 6-11.

IEC (2005) IEC Lecture Series - International Standardization in business, Industry, Society and Technology. Geneva: International Electrotechnical Commission.

IEC (2007) IEC Lecture Series II - The Importance of Standards. Geneva: International Electrotechnical Commission.

ISO (2011). The ISO 2011 Award for Higher Education in Standardization. Geneva: International Organization for Standardization.

ISO Focus + (2011) Society for standards and standardization launched. ISO Focus +, 2(1), 36.

Ketchell, J. (2010) Education about standardization - developing future generations of standardisers. Presentation at WSC Academic week, Geneva, 2010-07-05--09.

Krechmer, K. (2007). Teaching standards to engineers. International Journal of IT Standards and Standardization Research, 5(2), 1-12.

KSA (2003). International workshop to develop a standardization education model. Proceedings. Seoul: KSA.

Kuhn (1962). The Structure of Scientific Revolutions. Chicago: University of Chicago Press.

Kurokawa, T. (2005). Developing Human Resources for International Standards. Quarterly Review, No. 17, October 2005, Retrieved from http://www.nistep.go.jp/achiev/ftx/eng/stfc/stt017e/qr17pdf/STTqr1703.pdf

Lee, G. (2007). Universities in the Republic of Korea: Training the next generation of prefessionals. ISO Focus, 4(11), 17-18.

NEN (2010). Annual Report 2009 - Crisis \& Control. Delft: NEN. 
Nonaka, R. (2010). New approach on the pedagogy for standards education: A case of Applied Standards Education at TUAT. In Proceedings of International Symposium on Standardization Education and Research 2010, pp 156-167. March 19-20, 2010 Hangzhou, China. Hangzhou: China Jiliang University / Tokyo: Tokyo University of Agriculture and Technology.

Odjar Ratna Komala, D. (2011) Mechanics of Developing a University Level Standards Education Program in Indonesia. Presentation held at the 2011 PEC SCSC PAGE - ANSI CoE Workshop February 28, 2011, Washington DC, US.

Orgalime (2010a). Draft Orgalime comments on EP IMCO report on the Future of European Standardization. Position paper. Brussels: Orgalime.

Orgalime (2010b). Review of the European Standardization System. Position paper. Brussels: Orgalime.

Schepel, H. (2005). The Constitution of Private Governance - Product Standards in the Regulation of Integrating Markets. Oxford and Portland, OR: Hart Publishing.

Serenkov, P. (2010). Belarus - Training tomorrow's experts today. Retrieved May 26, 2010, from http://www.iso.org/iso/iso-focus-plus_index/iso-focusplus_online-bonus-articles/the2009-iso-award/2009-award belarus.htm

Song, M. (2007). Guest View. ISO Focus, 4(11), 4-7.

Spivak, S.M., \& Kelly, W.E. (2003). Introduce strategic standardization concepts during higher education studies ... and reap the benefits! ISO Bulletin, 34(7), 22-24.

Swann, G.M.P. (2010). The economics of standardization - An Update. report for the UK Department of Business, Innovation and Skills (BIS). Innovation Economics Limited.

Verman, L.C. (1973). Standardization - A new discipline. Hamden, CT: The Shoe String Press / Archon Books.

Yamada, H. (2011) Development of Education on Standardization in Japan. Presentation held at the 2011 PEC SCSC PAGE - ANSI CoE Workshop February 28, 2011, Washington DC, US.

Yang, Y. (2010). China Institute of Metrology's Educational Model for Standardization. China Standardization, 37(1), 15-21.

Zachariadou, K, Zachariadis, A., \& Latinopoulou, M. (2010). Contributions of the Bulgarian Union of Standardization for the European Integration of the Republic Bulgaria. In: Mijatovic, I. and Živković, N. (Eds). Proceedings $7^{\text {th }}$ International Conference "Standardization Protypes and Quality: A means of Balkan countries collaboration", pp 7882. June 8-9, 2010 Zlatibor, Serbia. Belgrade: University of Belgrade, Faculty of Organizational Sciences. 
Henk J. de Vries, Associate Professor of Standardisation, Rotterdam School of Management, Erasmus University Rotterdam, the Netherlands (Hvries@rsm.nl, (+31 10) 40820 02, http://www.rsm.nl/hdevries). Henk's research and education focus on standardization from a business point of view. Henk is Vice-President of the European Academy for Standardization EURAS, Vice-Chair of the International Cooperation on Education about Standardization ICES, Special Adviser to the International Federation of Standards users IFAN, member of the Dutch Academy for Quality DAQ, member of the Dutch Platform for Open Standardization, and member of the CEN/CENELEC/ETSI Joint Working Group on Education about Standardization. 
Publications in the Report Series Research* in Management

ERIM Research Program: "Business Processes, Logistics and Information Systems"

2011

Sequencing Heuristics for Storing and Retrieving Unit Loads in 3D Compact Automated Warehousing Systems Yugang Yu and René B.M. De Koster

ERS-2011-003-LIS

http://hdl.handle.net/1765/22722

A Local Search Algorithm for Clustering in Software as a Service Networks

Jelmer P. van der Gaast, Cornelius A. Rietveld, Adriana F. Gabor, and Yingqian Zhang

ERS-2011-004-LIS

http://hdl.handle.net/1765/22723

Implementing Standardization Education at the National Level

Henk J. de Vries

ERS-2011-007-LIS

http://hdl.handle.net/1765/22812

* A complete overview of the ERIM Report Series Research in Management: https://ep.eur.nl/handle/1765/1

ERIM Research Programs:

LIS Business Processes, Logistics and Information Systems

ORG Organizing for Performance

MKT Marketing

F\&A Finance and Accounting

STR Strategy and Entrepreneurship 